\title{
Does Language Aptitude Make a Difference? An Investigation of the Effect on Oral Accuracy through Corrective Feedback
}

\author{
Ali Mohammadi Darabad \\ M.A Graduate in TEFL \\ PO Box 13518 - 57195, Tehran, Iran \\ Tel: 98-912-7070-951Ｅ-mail: Mohammadi.ali741@gmail.com
}

Received: July 5, 2013 Accepted: August 2, 2013 Published: August 25, 2013

doi:10.5296/ijl.v5i4.4199 URL: http://dx.doi.org/10.5296/ijl.v5i4.4199

\begin{abstract}
The aim of this study is to explore the effect of corrective feedback (prompts and recasts) on oral accuracy with the emphasis on language aptitude. The initial participants of this study were 120 male Iranian elementary learners (15-20 years old) studying English as a foreign language. Their language aptitude was measured by the Words in Sentence component of the Modern Language Aptitude Test-Elementary (MLAT-E) (2002). The Key English Test 2 (2003) was conducted as a placement test. 60 learners were selected using the results of placement and aptitude tests and randomly assigned into three groups (prompt, recast, control) each of them containing 20 members. The study followed placement test, MLAT-E, pre-test, treatment sessions, immediate post-test, and delayed post-test design. A mixed between-within subjects analysis of variance was conducted to assess the impact of prompts and recasts on participants' oral accuracy across three time periods (pre-intervention, post-intervention, three weeks follow-up). The results showed that there was a statistically significant interaction between the use of corrective feedback and the time. The main effect comparing the two types of intervention was statistically significant suggesting a significant difference in the effectiveness of the two teaching approaches showing the superiority of prompts over recasts in post-tests. In the meantime, the results didn't show any interaction between aptitude and feedback conditions in terms of target language accuracy.
\end{abstract}

Keywords: Corrective feedback, Prompt, Recast, Aptitude 


\section{Introduction}

One of the concerns of EFL teachers in second language acquisition is error correction that has been debated for so long. The issue of error correction has led to the conduction of many theoretical and empirical studies. In this vein, providing the learners with only positive evidence or exposing them to negative evidence as well are the main concerns of English teachers. The advocates of nativist paradigm believe that providing the positive evidence for language learners is sufficient; however, interactionist scholars (e.g., Gass, 2003) believe that providing negative evidence is also required. Gass (1997) declares that the term negative evidence is often used interchangeably with the terms negative feedback and corrective feedback to refer to any erroneous utterances of language learners.

Looking through the annals of error correction (e.g., Brown, 2007; Larsen-Freeman, 2000; Richards \& Rodgers, 2001) we can observe that errors were considered as taboos and should be corrected immediately in the discourse of some schools of thoughts like behaviorism. On the other hand, others claimed that error correction was not only unnecessary, but also harmful to language learning (Krashen, 1981a; 1981b). According to Nicholas, Lightbown, and Spada (2001) and Russell (2009), with the advent of communicative approaches, error correction experienced a fundamental change. The followers of communicative language teaching (CLT) established equilibrium between what Audiolinguists and Cognitistvists do and recommended that an error must be considered as evidence of language students' linguistic development, not as a taboo to be refrained. Since the followers of CLT spotted the requirement for fluency, this allowed the teachers to leave some errors uncorrected.

In communicative classes, the main concern of teachers is whether to correct the learners' erroneous oral production through non-target forms or not. In fact, most teachers have a tendency to correct errors, but the important point is that the teachers are not provided with enough knowledge in terms of 'what', 'how', and 'when' of correction. Even if we refer to the research studies, we would be faced with some confusing and contradictory results. Due to the effects of content-based and communicative approaches on L2 teaching, the teachers consider errors as evidence of learners' linguistic development. As a result of these effects, it was believed that errors represent the learners' creative attempt to use language beyond what they have been taught. According to Nicholas, Lightbown, and Spada (2001), there has even been a debate over not correcting errors.

Paying attention to such approaches, L2 learners in communicative classes continue to experience difficulties with accuracy, although they come to attain relatively high levels of comprehension ability and, to some extent, fluency in oral production (Ammar \& Spada, 2006, Mohammadi Darabad, 2013a, 2013b). Some studies have shown that recasts are the most frequently used technique in the language classrooms (Braidi, 2002; Iwashita, 2003; Lyster \& Ranta, 1997; Panova \& Lyster, 2002; Sheen, 2004), but their noticeability and effectiveness in promoting L2 learning have not been totally approved.

According to Lyster (1998a), recasts are not considered as the most effective corrective feedback technique in leading to well-formed use of the reformulated utterance. He believes that non-corrective repetitions and recasts have similar forms and functions and are used 
interchangeably. However, immediate response to teachers' reformulations does not guarantee the noticing of the reformulated utterance. According to Ammar and Spada (2006), learners' ability to notice recasts is quite limited. It is even more limited when provided in reaction to the utterances of low proficient learners.

On the other hand, in comparison with prompts, recasts are less effective. Some researchers (e.g., Lyster, 1998a, 2004; Lyster \& Ranta, 1997; Panova \& Lyster, 2002; Mohammadi Darabad, 2013a, 2013b) argue that the reason for superiority of prompts over recasts is that the teachers provide the correct forms for learners and the learners are not forced to modify their own utterance or what Swain and Lapkin (1998) called 'pushed output'. Lyster (1998b) believes that prompts push learners implicitly or explicitly to reformulate an erroneous utterance into a correct form so that opportunities are provided for self-repair, whereas recasts involve other-generated repair.

To put shed on the issue of the probable superiority of prompts over recasts, we decided to investigate the issue with the presence of another aspect, i.e., aptitude, the effect of which has not still been examined. The concern is whether aptitude mediates the effects of recasts and prompts on L2 development. The importance of aptitude should not be overlooked. Studies have shown that aptitude is a real and valid component of language learning deserving enough research attention in foreign language instruction (e.g., Albert, 2006; Banks, 2008; Child, 1998; Cobb, 2007; Ehrman, 1998; Robinson, 1997).

In this research, an attempt was made to examine the effects of corrective feedback techniques (i.e., prompts and recasts) on the target language grammatical accuracy (i.e., simple past tense) and then scrutinize the effect across learners' language aptitude to inspect the probable mediating effect of this construct on the $\mathrm{CF}$ techniques in leading to grammatical accuracy of Iranian male foreign language learners.

\section{The Literature Review}

Aptitude is defined as the individual's initiate state of readiness and capacity for foreign language learning and probable facility for doing so (Carroll, 1981). Carroll further argues that aptitude reflects a prediction for proficiency and a potential rate of acquisition by older learners as well; such a prediction can be made under optimal conditions of motivation, opportunity and quality of instruction. The role that aptitude plays in achievement can vary as these variables vary although remains constant.

The concept of foreign language aptitude does not mean that some people are able to learn foreign languages while the others are not. Under the right condition and being cognitively healthy all people are considered to be able to learn a foreign language. The only thing that aptitude is believed to do is to determine the ease and rate with which a particular individual would successfully acquire a language (Carroll, 1981). Considering the fact that all individuals might have the ability to achieve success with a foreign language, it is believed that those with lower aptitude might do so with a great difficulty and over a longer period of time.

Robinson (2001) proposed Aptitude Complex Hypothesis (ACH) in which he believed that 
there is hierarchical structure of abilities for language learning in instructed second language acquisition. According to Doughty (2001), for measuring aptitude for learning from some techniques of "focus on form" delivered during communicative classroom some of these abilities may be appropriate.

As far as foreign language is concerned, aptitude is not only hypothesized as a unitary construct, but also is a cluster of different cognitive traits that are advantageous (Oxford \& Ehrman, 1992). To maximize the learning strengths and to minimize the weaknesses there needs to be more language program to adapt to learners' cognitive abilities for L2 learning. We might say that some learners show higher aptitude in one style of language program than others do. For example, some learners' aptitudes or sets of abilities may be more suited to learning from one focus on form technique than from another.

$\mathrm{ACH}$ claims that certain sets or combinations of cognitive abilities are involved in learning under one condition of instructional L2 exposure versus another (Snow, 1994). Not all the learners have equivalent aptitudes to get the advantage of one instructional technique in learning a foreign language. Snow (1994) believes that practice should take place under those conditions to which individuals' aptitudes are best matched if the effects of practice are to be optimized.

\subsection{The Modern Language Aptitude Test}

The first model of language aptitude was developed by Carroll (1962). The tests that he developed hypothetically represented capacities involved in foreign language learning. The performance on these tests then was correlated with tests of foreign language proficiency. From the tests he retained, he developed the Modern Language Aptitude Test (MLAT) and proposed that the construct of aptitude was made up of four components: (a) phonetic coding ability, (b) grammatical sensitivity, (c) rote learning ability for foreign language materials and (d) inductive learning ability (Skehan, 2002).

Skehan (1998) has adapted Carroll's model to an information-processing model of language acquisition along with recent research in cognitive psychology. According to Skehan (2002), general learning mechanisms determine the success at foreign L2 language learning. He proposes that language learning are modular, different from those that exist in L1 learning, and related to different stages in the perception, analysis, storage and retrieval of information as it passes through the learner's information-processing system.

\subsubsection{Phonemic Coding Ability}

Phonemic coding ability concerns the effective auditory processing of input (Skehan, 1998; 2002). It is important in allowing the learner to analyze and code auditory material for the purpose of retention, often in real time. It is particularly important at beginning stages of language learning and it affects crucially how much comprehensible input is available to the learner for the next stage of processing (Skehan, 2002).

\subsubsection{Language Analytic Ability}

Language analytic ability is the ability of inferring rules of learning or making linguistic 
generalization. Skehan (1998) believes that this ability is necessary to the central stage of information processing.

According to Carroll (1962), there are two separate components to this ability: grammatical sensitivity and inductive language analytic ability (although his MLAT did not include a measure of the latter). Skehan (1989) suggests that language analytic ability is more closely related to general measures of intelligence and he is unclear because of the kinds of structures and processes that operate at this stage. If the learner still has access to Universal Grammar, then an ability that is qualitatively different from general learning mechanisms may be at work; if not, then more general cognitive processes may play the dominant role.

Ehrman and Oxford (1995) conducted a research in which the results indicated that language analytic ability was a good predicator of success in L2 learning. The relationships of a variety of individual difference variables to end-of-training proficiency ratings for a large sample of learners receiving instruction in a variety of languages had been examined. They found that one of the individual difference variables that correlated most strongly with proficiency was the performance on the Words in Sentences subtest of the MLAT.

\subsubsection{Memory}

Memory is one of the components of aptitude that has received the greatest attention. Some works in cognitive psychology have led to the concept of working memory instead of short-term memory (Carroll, 1962). Baddeley (1999) stipulated that working memory is responsible for both manipulating and temporarily storing information. There are three components to working memory: the central executive, the phonological loop and the visuo-spatial sketchpad. According to Baddeley (1999), the central executive is the component that is most complex and least understood. It is capacity limited and used for the processing and storage of information at the same time.

Traditional measures of working memory (e.g., the Digit Span Test of Gathercole et al., 1997) evaluated storage only. Daneman and Carpenter's Reading Span Test (1980), which requires students to recall auditory input while processing it at the same time, has been used as an index of working memory capacity in many studies. In a research conducted by Harrington and Sawyer (1992), the results indicated that learners with greater working memory capacity outperformed their counterparts on measures of L2 reading skill. Mackey et al. (2002) propose a possible link between the capacity of working memory and the ability to benefit from interactional feedback in an L2 learning context.

Baddeley (1999) describes the phonological loop as a specialized unit for the retention of verbal information over short periods of time. He further argues that this loop is composed of two units: the phonological store and the sub-vocal articulatory rehearsal process. The phonological store holds information in phonological form and is subject to decay and interference. The sub-vocal articulatory rehearsal process recodes non-auditory material into a form suitable for the phonological store and maintains decaying representations in the phonological store. Phonological loop capacity has been operationalized in the research literature (e.g., Gathercole \& Martin, 1996; Gathercole et al., 1991) as the ability to repeat 
non-words immediately following presentation. Phonological loop capacity has been shown to be predictive of both L1 and L2 vocabulary acquisition (Gathercole \& Baddeley, 1989; 1990). The role of phonological working memory has been investigated in L2 learning in a few studies. Ellis and Sinclair (1996) emphasized on the role of phonological working memory in idiom learning. He quotes a number of studies that have demonstrated the correlation of phonological working memory with grammatical ability.

Skehan (1998) suggests that the importance of memory in language learning may have been greatly underestimated. He stresses the role of memory at the output stage of language processing but also allows for a role for memory within the input-processing stage. He claims that noticing must take place within working memory and suggests that those learners who are the more effective input processors will have greater working memory attentional capacity.

\subsection{Aptitude, Attention, and Focus on Form (FonF) Techniques}

Various focus on form (FonF) techniques have been employed to manipulated the degree of attention to forms in L2 communicative classes. Among these techniques are input flooding, input enhancement, recasting, and structured input processing with and without rule explanation. Findings for research into less communicatively intrusive FonF techniques have produced mixed results to date, with some studies showing input enhancement and recasting to have an effect on subsequent L2 learning, but not others. One reason for this may be that in any studied population some L2 learners' aptitudes, or sets of abilities, are more suited to learning from one FonF technique versus another.

Two studies specified that this may be so with regard to recasting. In a research for finding the relationship between measures of phonological working memory capacity and noticing of information targeted by recast (features of wh-question formation) using students at arrange of levels in a foreign language EFL program, Mackey et al. (2002) found significant positive relationship. However, learners at lower developmental levels outperformed the learners at higher ones.

Similarly, Robinson (1999), and Robinson and Yamaguchi (1999) found high significant positive correlations of measures of phonetic sensitivity and also rote memory (using Sasaki's Language Aptitude Battery for the Japanese, LABJ, 1996), with learning from recasts by university-level, non-language majors, during task-based interaction over a five-week period.

The findings for a positive relationship between phonetic sensitivity, memory ability and learning from recasts in Robinson and Yamaguchi's (1999) study, and phonological working memory capacity and noticing of recast information in Mackey et al. (2002) suggest that these abilities are positively implicated in aptitude for learning from the recasting FonF technique.

However, as with the finding for incidental learning in Robinson (1997), in Robinson and Yamaguchi (1999) there were no significant correlations of learning of relative clauses during task-based interaction (supplemented by targeted recasts) and the grammatical sensitivity aptitude subtest. These findings allow an inference across contexts (laboratory studies of 
incidental learning, and classroom studies of focus on form during task-based learning) about the non-influence of individual differences in grammatical sensitivity on incidental learning during processing for meaning. These findings suggest that learners may differ in their aptitude(s) for learning from one FonF technique versus another.

According to Robinson (1997), the correlations between Grammatical Sensitivity scores and the performance on easy and difficult rules for implicit participants are significantly positive. On the other hand, in Reber's (1989) study no significant positive correlation was predicted between the measure of Grammatical Sensitivity and implicit learners' performance on complex rules. One explanation for these findings is that some of the learners in the implicit condition began to consciously scrutinize, look for and find the rules underlying the presented sentences. The Grammatical Sensitivity is the component of aptitude that predicts learners' accuracy on both rules, not Memory. This occurs despite the fact that the implicit task instructions predisposed the participants to rely on memory, and despite the claims that knowledge gained in implicit conditions in Reber's experiments is the result of memory. If such knowledge had arisen from exposure to the implicit condition here and had guided the participants' grammaticality judgments, then the results should have shown a stronger correlation between Memory scores and implicit learning.

Though the results for the positive effect of superior aptitude on implicit learners' performance was somehow against Reber's (1989) claims, the result for incidental learners supports Krashen's (1981) claim that individual differences (assessed by aptitude tests) do not influence acquisition processes stimulated by a focus on meaning. In Robinson's (1997) research, individual differences and fundamental similarity of implicit and explicit adults' second language learning, the results show that there are no significant correlations of accuracy on easy or hard rules with the scores obtained on the aptitude subtests. As predicted by Krashen, there are significant correlations of accuracy on easy and hard rules with both Grammatical Sensitivity and Memory scores for instructed participants. The aptitude/accuracy correlations for Rule-search participants also fit Reber's predictions. Grammatical Sensitivity scores correlate significantly with Rule-search accuracy on the easy rule, suggesting that, as Reber has claimed, looking for rules will help if the rules are easy. Additionally, these data suggest that if the learners are sufficiently sensitive to the grammatical regularities of the structures to be learned, L2 learners' looking for rules that are easy will work. In addition, accuracy on hard rules significantly correlates with Memory scores, suggesting that where the stimulus domain is complex, memory-based processing strategies are most effectively developed during rule-search.

\section{Methodology}

\subsection{Participants}

Initially, 150 Iranian EFL learners (18-25 years old) of English at elementary level from different language institutes in Ardabil (an Iranian northwest city) participated in this study. Of these participants, based on the scores taken from Placement Test and Words in Sentence component of the Modern Language Aptitude Test-Elementary (MLAT-E), 78 learners were selected. Half of them were specified as high aptitude (HA) and the other half were specified as 
low aptitude (LA). The participants were randomly assigned into two experimental groups (recast and prompt) and one control group. Each group had 13 HA and 13 LA learners. 60 participants attended the placement test, MLAT-E, the pre-test, the treatment sessions, the post-test, and the delayed post-test and the data obtained from 60 participants were taken for analysis.

\subsection{Materials}

In this study, we employed the Key English Test 2 (KET) (2003) for homogenizing the classroom participants. For determining the high or low aptitude learners, Carroll and Sapon's Modern Language Aptitude Test - Elementary (MLAT-E) (2002) was employed. This was an adaptation of the adult version of the MLAT intended for younger students. Interchange 1 Third Edition by Jack C. Richards, 2009, was the course book in the target institute. Elementary Stories for Reproduction by L. A. Hill, 2001, was used for oral retelling.

\subsection{Procedure}

The design of this study was a placement test administration, MLAT-E administration, pre-test, treatment sessions, immediate post-test, and delayed post-test one which lasted for 20 sessions.

\subsubsection{Placement Test}

The placement test contained two parts: written and oral. The written part consisted of listening (20 items), reading (20 items), and language use (30 items). The oral part was a 10-minute, face-to-face interaction with individual students. The written test was conducted with whole class attending at once but the oral test was administered individually. 60 minutes were allotted for each individual's placement test.

\subsubsection{Determining High and Low Aptitude Participants}

After conducting the placement test, the participants attended the MLAT-Elementary (MLAT-E). Subjects who scored above the group mean were considered to be high aptitude learners while subjects who scored below the group mean were considered to be low aptitude. The MLAT-E is considered a standardized instrument and has been tested for validity and reliability (e.g., M. M. Suarez Vilagran, 2010).

\subsubsection{The Pre-test}

After the target structural feature (i.e., simple past tense) was taught, the individuals were given a short story selected from Elementary Stories for Reproduction. They were supposed to work on the stories for ten minutes; typically, five minutes to read the story and another five minutes to retell the story. Their voices were tape-recorded and then transcribed for forthcoming analyses.

\subsubsection{Treatment Sessions}

In the treatment sessions, a controlled practice of reading a short story was made in which the participants were divided into the groups of three or four and then they were asked to retell their story. For this to happen, a copy of one of the short stories was given to the individual 
members of the groups. They were supposed to read the stories silently in 5 minutes and then retell the story to the other members of the same group. Whenever needed, the teacher would provide the necessary explanation or clarify the probable problematic words. After working on the stories, one of the members of each group was randomly chosen to retell the story to the class. CF techniques in the experimental groups (i.e., prompts and recasts) were employed on the learners' erroneous utterance with whole class attending. Later on, a semi-controlled practice was provided to make sure that all the individual learners were aware of the procedures for retelling their stories. It is worth mentioning that recasts and prompts were provided on past tense errors to individual students with the whole class attending in the experimental groups in every session. This procedure was followed in all the experimental groups. However, the control group didn't get the treatments.

\subsubsection{The Immediate Post-test}

In this part, the learners were provided with some unseen short stories and then they were asked to randomly pick one of the stories. They were supposed to read the story silently in five minutes and retell it. At the same time, their voices were recorded. The unseen short stories were cautiously nominated and it was made sure that most of the difficult words in the stories had been taught during treatment sessions. The obtained data were booked for future analyses.

\subsubsection{The Delayed Post-test}

After three weeks, the participants attended a similar test (i.e., the delayed post-test) and the results were recorded for further analysis. The delayed post-test was run to inspect the probable effect of time on learning. The procedure in this phase was the same but the stories were different for the individuals. We exchanged the short stories between the experimental and control groups. To control for the test-retest effect, three different sets of short stories were used for each testing session.

Finally, the obtained results from the pre-test, the immediate post-test, and the delayed post-test were transcribed and rated and then plugged into the SPSS software version 18, two-way ANOVA (mixed between-within subject analysis) for analysis.

\section{Results}

To check whether the different feedback conditions, high and low aptitudes, and the interaction of them significantly contributed to the accuracy scores, a mixed between-within subject analysis (SPANOVA) was run on the tests, the results of which appear in the following tables. 


\section{Ml Macrothink}

Table 1. Descriptive statistics for the pre-test

\begin{tabular}{llccc}
\hline Group & Aptitude & M & SD & N \\
\hline prompt & High & 44.78 & 11.96 & 10 \\
& Low & 48.01 & 11.92 & 10 \\
& Total & 46.39 & 11.74 & 20 \\
recast & High & 49.06 & 8.63 & 10 \\
& Low & 51.72 & 10.14 & 10 \\
& Total & 50.39 & 9.26 & 20 \\
& High & 51.63 & 14.43 & 10 \\
control & Low & 48.76 & 10.01 & 10 \\
& Total & 50.19 & 12.18 & 20 \\
& High & 48.49 & 11.85 & 30 \\
Total & Low & 49.49 & 10.48 & 30 \\
& Total & 48.99 & 11.10 & 60 \\
\hline
\end{tabular}

The provided data in Table 1 for the pre-test display a little difference between the means and the standard deviations among the three groups of the study: prompts $(M=46.39, S D=11.74$, $N=20)$, recasts $(M=50.39, S D=9.26, N=20)$, control $(M=50.19, S D=12.18, N=20)$. It also shows the same statistical features for all of the participants in the three groups: total groups $(M=48.99, S D=11.10, N=60)$. This table also provides the statistical features of mean and standard deviation for both high aptitude (HA) and low aptitude (LA) participants in each group: prompt group HA participants $(M=44.78, S D=11.96, N=10)$, prompt group LA participants $(M=48.01, S D=11.92, N=10)$; recast group HA participants $(M=49.06, S D=8.63$, $N=10)$, recast group LA participants $(M=51.72, S D=10.14, N=10)$; control group HA participants $(M=51.63, S D=14.43, N=10)$, control group LA participants $(M=48.76$, $S D=10.01, N=10)$; total group HA participants $(M=48.49, S D=11.85, N=30)$, total group LA participants $(M=49.49, S D=10.48, N=30)$.

Table 2. Descriptive statistics for the immediate post-test

\begin{tabular}{llccc}
\hline Group & Aptitude & M & SD & N \\
\hline prompt & High & 80.11 & 6.25 & 10 \\
& Low & 81.00 & 5.15 & 10 \\
& Total & 80.55 & 5.59 & 20 \\
recast & High & 68.82 & 5.00 & 10 \\
& Low & 67.62 & 5.50 & 10 \\
& Total & 68.22 & 5.16 & 20 \\
control & High & 55.84 & 8.31 & 10 \\
& Low & 55.65 & 5.98 & 10 \\
& Total & 55.74 & 7.05 & 20 \\
Total & High & 68.25 & 11.96 & 30 \\
& Low & 68.09 & 11.82 & 30 \\
& Total & 68.17 & 11.79 & 60 \\
\hline
\end{tabular}




\section{NI Macrothink}

International Journal of Linguistics

ISSN 1948-5425

2013, Vol. 5, No. 4

The obtained data for the immediate post-test are provided in Table 2. The descriptive statistical features for the three groups of the study in this phase are presented as follows: prompt group $(M=80.55, S D=5.59, N=20)$, recast group $(M=68.22, S D=5.16, N=20)$, control group $(M=55.74, S D=7.05, N=20)$, total groups $(M=68.17, S D=11.79, N=60)$. In addition, the statistical features for HA and LA participants in the three groups are presented: prompt group HA participants $(M=80.11, S D=6.25, N=10)$, prompt group LA participants $(M=81.00$, $S D=5.15, N=10)$; recast group HA participants $(M=68.82, S D=5.00, N=10)$, recast group LA participants $(M=67.62, S D=5.50, N=10)$; control group HA participants $(M=55.84, S D=8.31$, $N=10)$, control group LA participants $(M=55.65, S D=5.98, N=10)$; total group HA participants $(M=68.25, S D=11.96, N=30)$, total group LA participants $(M=68.09, S D=11.82$, $N=30$ ).

Table 3. Descriptive statistics for the delayed post-test

\begin{tabular}{llccc}
\hline Group & Aptitude & M & SD & N \\
\hline prompt & High & 74.30 & 10.39 & 10 \\
& Low & 79.31 & 7.33 & 10 \\
& Total & 76.80 & 9.12 & 20 \\
recast & High & 69.05 & 3.41 & 10 \\
& Low & 68.12 & 7.05 & 10 \\
& Total & 68.58 & 5.41 & 20 \\
control & High & 56.15 & 10.34 & 10 \\
& Low & 60.79 & 13.93 & 10 \\
& Total & 58.47 & 12.18 & 20 \\
Total & High & 66.50 & 11.42 & 30 \\
& Low & 69.40 & 12.34 & 30 \\
& Total & 67.95 & 11.88 & 60 \\
\hline
\end{tabular}

Table 3 shows the descriptive statistical features in the delayed post-test. The data provided for all the groups of the study are as follows: prompt group $(M=76.80, S D=9.12, N=20)$, recast group $(M=68.58, S D=5.41, N=20)$, control group $(M=58.47, S D=12.18, N=20)$, total groups $(M=67.95, S D=11.88, N=60)$. In addition, the statistical features for HA and LA participants in the three groups are presented: prompt group HA participants $(M=74.30$, $S D=10.39, N=10)$, prompt group LA participants $(M=79.31, S D=7.33, N=10)$; recast group HA participants $(M=69.05, S D=3.41, N=10)$, recast group LA participants $(M=68.12$, $S D=7.05, N=10)$; control group HA participants $(M=56.15, S D=10.34, N=10)$, control group LA participants $(M=60.79, S D=13.93, N=10)$; total group HA participants $(M=66.50$, $S D=11.42, N=30)$, total group LA participants $(M=69.40, S D=12.34, N=30)$. 


\section{MIl Macrothink}

Table 4. Test of within-subjects effects

\begin{tabular}{|c|c|c|c|c|c|c|c|}
\hline Effect & & Value & $\mathbf{F}$ & Hypothesis df & $\begin{array}{c}\text { Error } \\
\text { df }\end{array}$ & Sig. & $\left(\eta_{p}^{2}\right)$ \\
\hline Time & WL & .249 & 79.76 & 2.000 & 53.000 & .000 & .751 \\
\hline Time*group & $W L^{80}$ & .463 & 12.45 & 4.000 & 106.000 & .000 & .320 \\
\hline Time*Aptitude & $W L^{88}$ & .965 & .962 & 2.000 & 53.000 & .389 & .035 \\
\hline Time*group *Aptitude & $W L^{\oplus 8}$ & .967 & .445 & 4.000 & 106.000 & .776 & .017 \\
\hline
\end{tabular}

** Wilk’s Lambda

Table 4 shows the statistical results for the within-subject effects. As it is shown in the table, the effect of time was statistically significant $(p<0005)$ in leading the feedback conditions to be effective during the treatment sessions: Wilk's Lambda $=.24, F(2,53)=79.76, p<.0005$, partial eta squared $=.75$ with both groups showing an increase on the scores of oral accuracy of the participants across three time periods. The interaction effect of time and group is also statistically significant at the alpha level of .05: Wilk's Lambda $=.46, F(4,106)=12.45$, $p<0005$, partial eta squared .32. The interaction effect of time and aptitude (high and low aptitude participants) was not statistically significant at the alpha level of .05: Wilk's Lambda $=.96, F(2,53)=.96, p>.05$, partial eta squared $=.03$ suggesting that aptitude (high and low) does not have a moderating effect in leading to grammatical accuracy of the participants in this study. The within-subjects effects table also does not show a statistically significant effect for the interaction among time, group, and aptitude in this study: Wilk's Lambda $=.96, F(4,106)$ $=.44, p>.05$, partial eta squared $=.01$.

Table 5. Levene's test of equality of error variances

\begin{tabular}{ccccc}
\hline Time & F & df1 & df2 & Sig. \\
\hline 1 & .6 .26 & 5 & 54 & .680 \\
2 & .771 & 5 & 54 & .575 \\
3 & 1.892 & 5 & 54 & .111 \\
\hline
\end{tabular}

To check the assumption of homogeneity of variances we refer to the Levene's test of equality of error variances (Table 5). In this case, the value for each variable is greater than $.05(.68, .57$, and .11); therefore, we have not violated the assumption of homogeneity of variances. 
Table 6. Tests of between-subjects effects

\begin{tabular}{llllllll}
\hline Source & $\begin{array}{l}\text { Type III sum } \\
\text { of squares }\end{array}$ & df & Mean Square & F & Sig. & $\left(\boldsymbol{\eta}_{\mathrm{p}}^{2}\right)$ \\
\hline Intercept & 685388.288 & 1 & 685388.288 & 5711.338 & .000 & .991 \\
Group & 5203.153 & 2 & 2601.576 & 21.679 & .000 & .445 \\
Error & 6480.262 & 54 & 120.005 & & & \\
\hline
\end{tabular}

Table 6 shows the between-subjects effects results for the groups (prompt and recast groups) of this study. It is clear that there is a statistically significant effect for the groups across the three time periods at alpha level of $.05(\mathrm{p}<.05)$. Therefore, we conclude that the main effect for group is significant. There was a significant difference between the oral accuracy scores for the two experimental groups. The effect size of the between-subject effect is also given in this table. The partial eta squared value for group in this case is .44 which shows a very large effect size. Comparing the means of prompt and recast groups reveals that both experimental groups outperformed the control group and the performance of prompt group was better than recast group in immediate and delayed post-tests (see Table 7).

Table 7. The oral accuracy scores for prompt, recast, and control groups across three time periods

\begin{tabular}{lccccccccc}
\hline Groups & \multicolumn{3}{c}{ Prompts } & \multicolumn{3}{c}{ Recasts } & \multicolumn{3}{c}{ Control } \\
\hline Time period & N & M & SD & N & M & SD & N & M & SD \\
Pre-intervention & 20 & 46.39 & 11.74 & 20 & 50.39 & 9.26 & 20 & 50.19 & 12.18 \\
Post-intervention & 20 & 80.55 & 5.59 & 20 & 68.22 & 5.16 & 20 & 55.74 & 7.05 \\
Three weeks follow-up & 20 & 76.80 & 9.12 & 20 & 68.58 & 5.41 & 20 & 58.47 & 12.18 \\
\hline
\end{tabular}

\section{Discussion and Conclusion}

As mentioned previously, we were following two intentions of leading this study. First, an attempt was made to examine the effect of prompts and recasts on target language grammatical accuracy of Iranian foreign language learners and at the same time the superiority of one CF technique to the other, and then inspect the effect across high and low aptitude learners to explore a probable mediating effect of these constructs on prompts and recasts in leading to grammatical accuracy. The results gave some support to the first alternative, but no statistically significant evidence was found to support the second alternative.

To the support of the first alternative, we could witness a statistically significant effect of prompt and recast on the participants' oral accuracy across three time periods of testing; both prompt and recast groups showed an increasing effect in their oral accuracy scores comparing with their counterparts in control group. The obtained result in this study is consistent with previous studies that advocated CF in the form of prompts and recasts for their facilitative role in L2 development (Lyster \& Saito, 2010; Mohammadi Darabad, 2013a, 2013b; Russell \& Spada, 2006). The superiority of prompt over recast is also supported in this study. Some studies demonstrated that in a range of instructional settings prompts lead to greater improvements in accuracy than do recasts (Ammar \& Spada, 2006; Ellis, 2007; Ellis et al., 


\section{$\Lambda$ Macrothink}

International Journal of Linguistics

ISSN 1948-5425

2013, Vol. 5, No. 4

2006; Loewen \& Philp, 2006; Lyster, 2004). Furthermore, the findings of this study are consistent with Yang and Lyster's (2010) study. In their study, prompts were more effective than recasts in leading to $\mathrm{L} 2$ accuracy.

In the meantime, it was aimed to find out whether there is a relationship between aptitude, i.e., high and low, and learners' responses to prompts and recasts in leading to the target language grammatical accuracy. The results revealed that in prompt group the high and low aptitude participants scored not that much mean difference in the immediate and delayed post-tests and the difference among them was not statistically significant. Additionally, in recast group, the results didn't show any statistically significant difference between high and low aptitude participants in the post-tests. It seems that aptitude didn't have a mediating role in this regard. Therefore, this study didn't find any interaction between aptitude and feedback conditions in terms of target language accuracy. However, in a similar study Rouhi and Hassanpour (2010) found a strong correlation between aptitude and effectiveness of recast in L2 accuracy. They found a strong correlation between the aptitude and effectiveness of recasts in L2 accuracy. They also state that aptitude plays a very important role in increasing the ability of the learners in order to notice corrective feedbacks through recasts. The results of the present study failed to find such a relationship in oral measurement.

The studies of language aptitude in SLA usually show a positive correlation between the degree of aptitude and foreign language proficiency development (e.g., Carroll \& Sapon, 1959; Skehan, 1989). The finding that aptitude is an important factor in foreign language learning is further substantiated by studies that have assessed the effects of aptitude as well as motivation or attitudes towards the language to be learnt (e.g., Reves, 1982). The results from these studies generally indicate that the degree of aptitude is the most reliable predictor of language learning success.

Bylund, Abrahamsson, and Hyltenstam (2009) showed that language aptitude was a reliable predictor of grammatical judgment test (GJT) performance in that a significant positive correlation was found between the participants' degree of language aptitude and their performance on the GJT. Ehrman and Oxford (1995) found that among individual differences it is language aptitude that correlates most closely with foreign language performance. In a Hungarian context, Nikolov and Ottó (2006) found that language aptitude was the best predictor of the achievement on proficiency tests at the end of the academic year in the case of beginner language learners. According to DeKeyser (2000), language aptitude demonstrated to be an important factor in L2 ultimate attainment, accounting for a large part of the variation among adult learners and in Abrahamsson and Hyltenstam's (2008) study to some degree among early learners.

In spite of the existing studies on the role of aptitude in language teaching contexts, we are still witnessing some controversial results in this domain. To find a more comprehensive conclusion in the effect of aptitude on different aspects of language learning and teaching, the importance of conducting other researches should not be overlooked. 


\section{Al Macrothink}

International Journal of Linguistics

ISSN 1948-5425

2013, Vol. 5, No. 4

\section{Acknowledgement}

I would like to express my gratitude to those who cooperated with me in fulfilling this attempt. Among them, I should mention of my colleagues, students and the language institutes in Ardabil province. I am also grateful to my friends for reviewing my paper, giving invaluable comments, and helping me in the data collection sessions.

\section{References}

Abrahamsson, N., \& Hyltenstam, K. (2008). The robustness of aptitude effects in near-native second language acquisition. Studies in Second Language Acquisition, 30, 481-509. http://dx.doi.org/10.1017/S027226310808073X

Albert, A. (2006). Learner creativity as a potentially important variable: Examining the relationship between learner creativity and level of proficiency. In M. Nikolov, \& J. Horvath (Eds.), Empirical Studies in English Applied Linguistics (pp.78-79). Pecs: Lingua Fraca Csoport.

Ammar, A., \& Spada, N. (2006). One size fits all? Recasts, prompts and L2 learning. Studies Second Language Acquisition, 28, 543-574. http://dx.doi.org/10.1017/S0272263106060268

Baddeley, A. D. (1999). Essentials of human memory. Hove: Psychology Press, Taylor \& Francis.

Banks, T. (2008). Foreign language learning difficulties and teaching strategies. California: University of California.

Braidi, S. (2002). Reexamining the role of recasts in native-speaker/non-native speaker interactions. Language Learning, 52, 1-42. http://dx.doi.org/10.1111/1467-9922.00176

Brown, H. D. (2007). Teaching by principles: An interactive approach to language pedagogy. New York: Pearson Education.

Bylund, E., Abrahamsson, N., \& Hyltenstam, K. (2009). The role of language aptitude in first language attrition: The case of pre-pubescent attriters. Applied Linguistics, 31(3), 443-464. http://dx.doi.org/10.1093/applin/amp059

Carroll, J. (1962). The prediction of success in intensive foreign language training. In R. Glaser (Ed.), Training, research, and education (pp. 87-136). New York: Wiley.

Carroll, J. (1981). Twenty-five years of research on foreign language aptitude. In K. C. Diller (Ed.), Individual differences and universalism language learning aptitude (pp. 83-117). Rowly: Newbury House.

Carroll, J. B., \& Sapon, S. M. (1959). The modern language aptitude test. New York: The Psychological Corporation. PMCid: 1929331

Carroll, J. B., \& Sapon, S. M. (2002). Modern Language Aptitude Test-Elementary: Manual. Rockville, MD: Second Language Testing, Inc., 2002.

Child, J. (1998). Language aptitude testing: Learners and applications. Applied Language 
Learning, 9, 1-10.

Cobb, M. (2007). The role of aptitude in foreign language learning. Dialogue on Language Instruction, 18, 49-56.

Daneman, M., \& Carpenter, P. A. (1980). Individual differences in working memory and reading. Journal of Verbal Learning and Verbal Behavior, 19(4), 450-466. http://dx.doi.org/10.1016/S0022-5371(80)90312-6

DeKeyser, R. (2000). The robustness of critical period effects in second language acquisition. Studies in Second Language Acquisition, 22, 499-533.

Doughty, C. (2001). Cognitive underpinning of focus on form. In P. Robinson (Ed.), Cognition and second language instruction (pp. 206-225). Cambridge: Cambridge University Press. http://dx.doi.org/10.1017/CBO9781139524780.010

Ehrman, M. (1998). The modern language aptitude test for predicting learning success and advising students. Applied Language Learning, 9, 31-70.

Ehrman, M. E., \& Oxford, R. L. (1995). Cognition plus: Correlates of language learning success. Modern Language Journal, $\quad 79(1), \quad 67$. http://dx.doi.org/10.1111/j.1540-4781.1995.tb05417.x

Ellis, N. (1996). Sequencing in SLA. Studies in Second Language Acquisition, 18, 91-126. http://dx.doi.org/10.1017/S0272263100014698

Ellis, N., \& Sinclair, S. (1996). Working memory in the acquisition of vocabulary and syntax: Putting language in good order. Quarterly Journal of Experimental Psychology, 49, 234-250.

Ellis, R. (2007). The differential effects of corrective feedback on two grammatical structures. In A. Mackey (Ed.), Conversational interaction in second language acquisition: A collection of empirical studies (pp. 407-452). Oxford: Oxford University Press.

Ellis, R., Loewen, S., \& Erlam, R. (2006). Implicit and explicit corrective feedback and the acquisition of L2 grammar. Studies in Second Language Acquisition, 28, 339-368. http://dx.doi.org/10.1017/S0272263106060141

Gass, S. M. (1997). Input, interaction, and the second language learner. Mahwah, NJ: Erlbaum.

Gass, S. M. (2003). Input and interaction. In C. J. Doughty \& M. H. Long (Eds.), The handbook of second language acquisition (pp. 224-255). Malden, MA: Blackwell. http://dx.doi.org/10.1002/9780470756492.ch9

Gathercole, S., \& Baddeley, S. D. (1989). Evaluation of the role of phonological STM in the development of vocabulary in children: A longitudinal study. Journal of Memory and Language, 28, 1-4. http://dx.doi.org/10.1016/0749-596X(89)90044-2

Gathercole, S., \& Baddeley, S. D. (1990). The role of phonological memory in vocabulary acquisition: A study of young children learning new names. British Journal of psychology, 81, 


\section{Macrothink}

439-454. http://dx.doi.org/10.1111/j.2044-8295.1990.tb02371.x

Gathercole, S., \& Martin, A. (1996). Interactive processes in phonological memory. In S. Gathercole (Ed.), Models of short term memory (pp. 73-100). Hove: Psychology Press.

Gathercole, S., Hitch, G., Service, E., \& Martin, A. (1997). Phonological short term memory and new word learning in children. Developmental Psychology, 33, 966-979. http://dx.doi.org/10.1037/0012-1649.33.6.966

Gathercole, S., Willis, C., Emslie, H., \& Baddeley, A. (1991). The influences of syllables and word likeness on children's repetition of non-words. Applied Psycholinguistics, 12, 349-367. http://dx.doi.org/10.1017/S0142716400009267

Harringtone, M. \& Sawyer, M. (1992). L2 reading skill. Studies in Second Language Acquisition, 14, 25-38. http://dx.doi.org/10.1017/S0272263100010457

Iwashita, N. (2003). Negative feedback and positive evidence in task-based interaction: Differential effects on L2 development. Studies in Second Language Acquisition, 25, 1-36. http://dx.doi.org/10.1017/S0272263103000019

Kim, J. H. (2004). Issues of corrective feedback in second language acquisition. Applied Linguistics, 4(2) 150-162.

Krashen, S. (1981a). Second language acquisition and language learning. Oxford: Pergamon Press.

Krashen, S. (1981b). Principles and practice in second language acquisition. Oxford: Pergamon Press.

Larsen-Freeman, D. (2000). Techniques and principals in language teaching (2nd ed.). Oxford: Oxford University Press.

Loewen, S., \& Philp, J. (2006). Recasts in the adult English L2 classroom: Characteristics, explicitness, and effectiveness. Modern Language Journal, 90, 536-555. http://dx.doi.org/10.1111/j.1540-4781.2006.00465.x

Long, M. H. (1996). The role of linguistic environment in second language acquisition. In W. C. Ritchie, \& T. K. Bhatia (Eds.), Focus on forming classroom second language acquisition (pp. 21-26). Cambridge: Cambridge University Press. PMid:8788608

Lyster, R. (1998a). Recasts, repetition, and ambiguity in L2 classroom discourse. Studies in Second Language Acquisition, 20, 51-81. http://dx.doi.org/10.1017/S027226319800103X

Lyster, R. (2004). Differential effects of prompts and recasts in form-focused instruction. Studies in Second Language Acquisition, 26, 399-432. http://dx.doi.org/10.1017/S0272263104263021

Lyster, R., \& Ranta, L. (1997). Corrective feedback and learner uptake: Negotiation form in communicative classrooms. Studies in Second Language Acquisition, 19, 37-66. http://dx.doi.org/10.1017/S0272263197001034 
Lyster, R., \& Saito, K. (2010). Oral feedback in classroom SLA: A meta-analysis. Studies in Second Language Acquisition, 32, 265-302. http://dx.doi.org/10.1017/S0272263109990520

Mackey, A., Philp, J., Egi, T., Fujii, A., \& Tatsumi, T. (2002). Individual differences in working memory, noticing of interactional feedback and L2 development. In P. Robinson (Ed.), Individual differences and instructed language learning (pp. 181-209). Amsterdam: John Benjamins.

Mohammadi Darabad, A. (2013a). Oral Accuracy, Field Dependent/Independent Cognitive Styles and Corrective Feedback. International Journal of English Language Education, 1(1), 204-221. http://dx.doi.org/10.5296/ijele.v1i1.3273

Mohammadi Darabad, A. (2013b). Attitudes towards foreign language, corrective feedback, and oral accuracy. International Journal of Linguistics, 5(2), 116-134. http://dx.doi.org/10.5296/ijl.v5i2.3563

Nicholas, H., Lightbown, P. M., \& Spada, N. (2001). Recasts as feedback to language learners. Language Learning, 51, 719-758. http://dx.doi.org/10.1111/0023-8333.00172

Nikolov, M., \& Ottó, I. (2006). A nyelvi elokészíto évfolyam: Az elso tanév eredményei angol és német nyelvbol [The intensive language preparatory year: Results of the first cohort of students in English and German]. Iskolakultúra, 5, 49-67.

Oxford, R. L., \& Ehrman, M. (1992). Where are we with language learning motivation? Modern Language Journal, 78, 512-514.

Panova, I., \& Lyster, R. (2002). Patterns of corrective feedback and uptake in an adult ESL classroom. TESOL Quarterly, 36, 573-595. http://dx.doi.org/10.2307/3588241

Reber, A. S. (1989). Implicit learning and tacit knowledge. Journal of Experimental Psychology: General, 118, 219-235. http://dx.doi.org/10.1037/0096-3445.118.3.219

Reves, T. (1982). 'What makes a good learner?’ $\mathrm{PhD}$ dissertation, Hebrew University.

Richards, J., \& Rodgers, T. (2001). Approaches and methods in language teaching. Cambridge: Cambridge University Press. http://dx.doi.org/10.1017/CBO9780511667305

Robinson, P. (1997). Individual differences and the fundamental similarity of implicit and explicit adult second language learning. Language learning, 47, 45-99. http://dx.doi.org/10.1111/0023-8333.21997002

Robinson, P. (1999). Second language classroom research in Japan: Issues, studies, and prospects. In T. Fujiomura, Y. Kato, \& R. Smith (Eds.), Proceedings of the 10th IUJ conference on second language research (pp. 93-116). Tokyo: International University of Japan.

Robinson, P. (2001). Individual differences, cognitive abilities, aptitude complexes, and learning condition in SLA. Second Language Research, 17, 368-392. http://dx.doi.org/10.1191/026765801681495877 


\section{$\Lambda$ Macrothink}

International Journal of Linguistics ISSN 1948-5425

Robinson, P., \& Yamaguchi, Y. (1999). Aptitude, task feedback and generalizability of focus on form: A classroom study. Waseda University, Tokyo.

Rouhi, A., \& Hassanpour, A. (2010). On time and immediate recasts, aptitude, and L2 accuracy. World Applied Science Journal, 11(2), 136-141.

Russell, J., \& Spada, N. (2006). The effectiveness of corrective feedback for the acquisition of L2 grammar. In J. Norris (Ed.), Synthesizing Research on Language Learning and Teaching (pp. 133-163). Philadelphia, PA: John Benjamins. PMCid:1621066

Russell, V. (2009). Corrective feedback, over a decade of research since Lyster and Ranta (1997): Where do we stand today? Electronic Journal of Foreign Language Teaching, 6(1), $21-31$.

Schmidt, R. (2000). Attention. In P. Robinson (Ed.), Cognition and second language instruction (pp. 3-32). Cambridge: Cambridge University Press. PMid: 11099805

Sheen, Y. (2004). Corrective feedback and learner uptake in communicative classrooms across instructional settings. Language Teaching Research, 8, 263-300. http://dx.doi.org/10.1191/1362168804lr146oa

Skehan, P. (1989). Individual differences in second language learning. London: Arnold. PMid:2803872 PMCid:1277362

Skehan, P. (1998). A cognitive approach to language learning. Oxford: Oxford University Press. PMCid:1728754

Skehan, p. (2002). Theorizing and updating aptitude. In P. Robinson (Ed.), Individual differences and instructed language learning (pp. 69-93). Amsterdam: Benjamin.

Snow, R. E. (1994). Abilities in academic tasks. In R. J. Sternberg, \& R. K. Wagner (Eds.), Mind in context: Integrationists perspective on human intelligence (pp. 3-37). New York: Cambridge University Press.

Suarez Vilagran, M. M. (2010). Language aptitude in young learners: The elementary modern language aptitude test in Spanish and Catalan. Doctoral Dissertation: Department of Flologia Anglesa i Alemanya.

Swain, M., \& Lapkin, S. (1998). Interaction and second language learning. The Modern Language Journal, 82, 320-337. http://dx.doi.org/10.1111/j.1540-4781.1998.tb01209.x

Yang, Y., \& Lyster, R. (2010). Effects of form-focused practice and feedback on Chinese EFL learners' acquisition of regular and irregular past tense forms. Studies in Second Language Acquisition, 32, 235-263. http://dx.doi.org/10.1017/S0272263109990519

\section{Glossary}

ACH: Aptitude Complex Hypothesis

CF: Corrective Feedback 
FonF: Focus on Form

KET: Key English Test

MLAT: Modern Language Aptitude Test

MLAT-E: Modern Language Aptitude Test-Elementary

LABJ: Language Aptitude Battery for the Japanese 